\title{
Cross-Cultural Communication Understanding in Business and Economics ESP Teaching
}

\author{
Berlin Insan Pratiwi \\ Universitas Putra Bangsa Kebumen, Indonesia \\ Email of corresponding author: bipratiwi@gmail.com
}

\begin{abstract}
Language teaching should have portions for cultural reviews and studies that are relevant to the topics and learners' needs. This research was qualitative descriptive aimed to describe the cross-cultural understanding implementation in business and economic ESP class. It is significant to describe the class realization toward cultural aspect understanding since the findings are expected to enhance future class preparation. Better cultural-based-prepared material is believed to bring a better social impact on learners. Lecturers' and students' perspectives based on several interviews were the basis for final finding construction. Three English lecturers were involved. Snowball sampling was the sampling method employed resulting in 40 students involved in interviews. In the context of business and economics ESP in Universitas Putra Bangsa, lecturers provided material related to cross-cultural understanding in verbal realization i.e. in the level of words, phrases, clauses, and sentences. The above levels were introduced by the lecturers with cultural and contextual approaches. Students expected more strategic-applicable utterances for daily communication in a workplace setting. Lecturers delivered the general importance of non-verbal cross-cultural understanding in the form of kinesics (eye contact and gesture), proxemics, and artifactual in a workplace setting. Kinesics was prominent, while proxemics and artifactual were least prepared. Students found practical activities in non-verbal cross-cultural understanding realization were interesting and challenging.
\end{abstract}

Keywords: communication; cross-cultural understanding; English for specific purposes

\section{INTRODUCTION}

Language learning is an inseparable process only of learning words and grammar. Although in the practice of language learning the emphasis is on the aspects of words and grammar, in fact in every language some rules are often unwritten. These rules are integrated into the language-use culture; referring to how the natives use their language. Concerning language in the learning process, the cultural aspect must also be studied by every language learner. It is widely agreed that in language teaching, learners need knowledge and skills in vocabulary and grammar and the ability to use language appropriately: socially and culturally (Douglas \& Frazier, 2001; Abusyairi, 2013, and Rondiyah, et al., 2017).

Culture develops in society as a form of repetitive behavior that forms a habit. Koentjaraningrat (2002) states that there are three manifestations of culture, one of which is a complex of patterned activities and actions of humans in society. In speech and writing, the language that is manifested in human-to-human communication reflects the character and self-culture of the human being as well as the non-material concrete cultural picture of the community as a group of speakers.

Kramsch (2013) states that the teaching of culture in language learning is still considered a matter of debate. Nevertheless, Abusyairi (2013) states that language and culture are two 
things that always go hand in hand. In addition, Rondiyah, et al. (2017) state that the process of learning a language will indirectly be connected with the process of studying culture. Many studies have been carried out to demonstrate the importance of cultural teaching in language teaching. This is due to the very close relationship between language and culture (Douglas \& Frazier, 2001). In the process of language learning, cross-cultural understanding is an important thing to do. This kind of understanding will become a basic knowledge of the reasons why certain groups of people view things in a certain and distinctive way when compared to other groups of people.

The form of culture that is included verbally in a language is the aspect of the prevalence of using words or terms in certain situations and conditions. This kind of knowledge is often overlooked in the language learning process. In learning business and economics ESP context which is included as part of 'auxiliary language' class must also include the culture of delivering messages (verbal and non-verbal) which includes the use of words, terms, kinesics elements, proxemics elements, and the like in authentic materials and real practice. Topics that are often studied in business and economic ESP are not only logicalinformative input, but also contain material of a social nature. This material specifically requires an understanding of cross-cultural communication to avoid misuse that can have social implications. This kind of language learning uses a communicative approach and authentic materials (Ratnasari, 2019).

Schulz (2007) states that there have been many studies that emphasize the importance of cultural understanding in developing cross-cultural competence in foreign language learning. Understanding culture also has a role in shaping the attitudes and motivation of students. Teaching cultural aspects in a language can increase students' motivation to learn the language (Amzah, et al., 2012). A study conducted by Ishi (2009) shows a link between the attitudes shown by the learner and the culture studied in the target language. This study describes the positive effect of cultural element inclusion in the learning process. It is proven that cultural element inclusion forms a positive attitude towards the target language from students' perspectives.

Velentzas and Broni (2014) state communication as an act of conveying information through speech, visualization, signals, writing, and habits. This action aims to create a common understanding of something. As a form of social interaction, communication is carried out by humans with various media and can be carried out across regions so that cross-cultural communication may occur. This kind of cross-cultural communication can be done verbally and non-verbally which requires an understanding of cultural differences.

In the view of business and economic perspectives, misperceptions in international business communication can occur due to cultural differences (Pratama, 2015). Cultural understanding in business and economic English for a specific purpose (ESP) is a necessity in facing the dynamics of the times and all of its changes. This is done as an effort to minimize failures in the implementation of business communication. This research is expected to be an illustration of business and economic ESP teaching which also emphasizes cross-cultural understanding in the process of teaching activity. Given this emphasis, learners can carry out cross-cultural communication in English with a minimum rate of possible cultural understanding misunderstandings. This research is expected to describe how the concept of cross-cultural communication understanding is implemented in a class situation. In addition, this research presents novelties in the combination of the 
concepts: communication, cross-cultural understanding, and ESP teaching in the fields of business and economics.

\section{METHOD}

Qualitative descriptive method was employed in this research. The researcher attempted to find information about cross-cultural communication understanding in business and economics ESP classes. This research was conducted in Universitas Putra Bangsa from March 2021 - September 2021. The subjects of this study were lecturers and students of English classes. Three English lecturers were involved. Snowball sampling was the sampling method employed resulting in 40 students involved in interviews. Data provided in this study was carried out by conducting one-to-one in-depth interviews. The interviews were in the form of semi-structured interviews indicating the researcher had a clear list of issues to be addressed. Questions to be answered were prepared and delivered in flexible question order. Flexibility is the main consideration since the interviewee might develop ideas and speak more widely on the issues raised (Denscombe, 2017). The information gained during interviews were captured in voice recording and field notes. While conducting the interviews, the researcher also filled in the table to list respondent responses for further analysis. The analysis began by reconfirming the recording and the field notes as an attempt to minimize any missed information. Orderly numbered recordings were played while field notes were read to find the important part in data reduction step. Table filling rechecking was also essential since the table was one of the core information sources needed to clarify. The filled table then became the fundament in the coding step, i.e. classifying informants' argument into sections. This coding step was followed by many arguments breakdowns played as factual class-case examples to build further discussion and to draw conclusions at the end.

\section{FINDINGS AND DISCUSSION}

\section{Verbal Communication}

Verbal communication is the most widely known communication as it appears in utterances, including the realization of words, phrases, clauses, and sentences. Kusumawati (2019) states verbal communication involves a set of symbols with predetermined rules to combine these symbols. This set of symbols and rules used and understood by a community is then referred to as language.

Johnson, et al. (2006) states many international business failures are ascribed to the lack of cross-cultural competence of business practitioners. In cross-cultural interactions, especially practices in the world of work in the business and economics fields, understanding the use of language at the level of words, phrases, clauses, and sentences is the main thing to support the functional definition of language as a medium for exchanging ideas.

Three informant-lecturers were agree that words, phrases, clauses, and sentences are core in every successful business communication. Yet, it is not a complete mission in delivering good word-based understanding. Lecturers also agreed to make context-andculture based understanding.

\section{Word-level}

The three lecturers agreed to mention words as the most basic language level that students have to learn. In addition, the native way of how words are used is also fundamental to 
study. In conducting English classes, lecturers paid attention to the different functions a word might have both in English and Indonesian. Forty (100\%) students were also agreeing on the significance of understanding words as the basis in conducting communication. In terms of word-level understanding, lecturers also agreed to highlight the different cultures implemented in the word "I", which has no social stratification level as it is in Indonesian. The same statement was uttered that this specific personal pronoun is mandatorily introduced in-class activity to make it clear about the different cultures English and Indonesian culture have. Further, one lecturer compiled different cultures contained in the word "we", which has two different explicit meanings in Indonesian but requires further consideration in English as there is clusivity deliberation. Thirty-four out of forty (85\%) students stated knowing the clusivity concept was interesting and important for their understanding basis on different personal pronoun cultures to be applied in communication.

Lecturers claimed the word-level understanding as the easiest understanding level to teach since students can access its meaning independently. Lecturers were agree that they emphasized the importance of knowing the context in delivering word-level cross-cultural understanding. This finding is supporting Pratiwi and Rakhmasari (2019) findings; conducting ESP class with a contextual approach is the proper one for it provides chances for students to see the word in the most proper case and situation.

\section{Phrase-level}

In the context of ESP in this study, forty (100\%) students mentioned the importance of knowing business and economics English phrases. The three lecturers were in the same line; stating that the use of language at the phrase level is mandatorily exemplified for which phrases require an understanding of usage prevalence in English native point of view. In other words, it was stated that there is an English native culture of using phrases in business and economics ESP that should be conveyed in the learning process.

A lecturer brought examples of phrase-level understanding in an interview: 'work for' and 'work on' as phrases with common forms of usage with certain characteristics. In Indonesian, both phrases mean the same 'bekerja di' or 'bekerja pada', but in this study context of business and economics ESP, both phrases have significant differences. This study revealed that forty $(100 \%)$ students roled as informants once did not think that 'work for' and 'work on' have different functions in English-native-business-setting. They agreed that this is phrase-level understanding is prominent to learn.

\section{Clause and sentence-level understanding}

Teaching English sentences in the scope of business and economics setting requires more carefulness and thoughtfulness. Fadeeva and Kalinin (2012) state that the actual use of words in conversation is substantially defined by knowledge of the social and cultural life of speakers using the language. Lecturers conducting business and economics ESP classes agreed on the point of difficulty in adjusting to English nuance when it comes to clause and sentence level of cultural understanding. An example was brought by a lecturer, i.e. in telephoning scene: En - 'It's Mark (here)' or 'This is Mark (here)' (Mascull, 2010); meanwhile Ina-'Dengan Doni', 'Saya Doni'.

Yuryeva (2019) states that the communication culture of English speakers is characterized by a formal communication style based on the principle of keeping the distance between the interlocutors. This concept is applied in English class. Lecturers emphasized the importance of distance and equality in social relations in conducting English classes. In 
English class, students were introduced to the concept of low/high-context language to make it clear for them to understand the different status quo between English and Indonesian. Although English is classified as a low-context language, yet in verbal communication practice of business and economics ESP settings also adopts implicit intent. A thing that should be emphasized in business and economic ESP learning is that the use of small talk plays as a conversation starter. Students found it a really interesting topic to discuss further to gain more insight about the right and common small talk in a business setting situations. It is said by the students knowing the right meaning of the small talk will decrease their chance to trap in delivering the wrong answers.

\section{Non-Verbal Communication: Kinesics}

Littlejohn and Foss (2009) state kinesics as a study and interpretation of human body movements that can be taken as symbolic or metaphorical in social interactions. Jolly (2000) states kinesics as a paradigm to view ethology more universally regarding human behavior. The kinesics element in communication is realized in facial expressions, gestures, and postures. Each region has a function and meaning of its own kinesics message for its people. An understanding of this kinesics aspect should be a special review in business and economics ESP teaching emphasized as a provision for crosscultural communication.

\section{Eye Contact}

The human face has a significant role in communication which often shows the original meaning of the message conveyed since it brings various emotions. In general, the use of facial expressions in Indonesian culture and English culture has similarities, but there are significant differences also in terms of eye gaze. Eye gaze as part of forming facial expressions needs attention from the aspect of politeness aspect.

Three lecturers emphasized the importance of eye contact', meanwhile twenty-seven out of forty $(67.5 \%)$ students considered it as a necessity to understand. Javanese culture as the cultural background of the twenty students involved in this research was the main perspective in interviewing students. Thirty out of forty $(75 \%)$ students agreed not to stare at people in most setting. They were of the opinion that staring others eyes reflects rudeness and impoliteness. Meanwhile, three lecturers were underlining the importance of eye gaze in English communication since in regulating verbal communication, eye gaze is used optimally to indicate readiness to speak as well as an invitation for others to speak. This opinion is in accordance with Hans and Hans (2015) statement saying that a speaker can use eye contact to determine whether the interlocutor is involved in the conversation and determine the interlocutor's feelings which then being the signal can be used to adjust the message conveyed.

The aspect of eye gaze in face-to-face communication in English culture is different from eye gaze culture in Indonesia. Indonesian people, especially Javanese, have a culture of looking into the eyes with a looser gaze intensity. Javanese social culture is concerned with high respect toward other people, especially to the older and elder. Compared to English-speaking culture, social hierarchy in Javanese society can be easily seen because it is reflected in people daily behavior. For Javanese people eye gazes can actually be considered as things that do not fulfill the function of decency and politeness as uttered by Poedjosoedarmo (2017).

The different gaze concepts in cultures should be part and concern in business and economics ESP teaching. Learners need to get used to make adjustments to English 
culture of kinesics non-verbal communication in the form of eye gaze. In class activity the three English lecturers brought the culture of face-to-face communication in native English speakers that is looking at the other person's eyes. Scott, et al. (2019) states that the gaze of a listener's eyes from the speaker's eyes to all areas of the speaker's face is a form of response in direct eye contact. Regarding the culture of eye contact with English speakers, in the study of Dutch, Hömke, et al. (2017) states that in Dutch-speaking culture the blinking of an eye in a face-to-face conversation is a form of feedback from the recipient of the message.

Lecturers were agree that eye gaze serves as a form of receiving messages non-verbally and is an important part of human non-verbal communication which requires attention. Lecturers made it clear that the eye contact should be made in this context is eye gaze that is not always focused on the eyes, but sweeps across the face of the interlocutor. In addition, in English-speaking cultures, eye gaze can also be used as a measure of one's self-confidence. Thirty seven out of forty (92.5\%) students were agreeing that maintaining a proper eye gaze is a challenging task.

\section{Gesture}

In this study, examples of commonly used gestures by English native speakers were presented in the form of hand movements accompanying verbal speech. For the people of Javanese this gesture usage is not a common thing, especially with the diverse language stratification used in communication. Prakoso (2019) states that Javanese people are very attentive and careful about indirectness and implicitness in communication and always avoid conflict in communication.

In the context of the world of work which is included in business and economics ESP, the practice of delivering presentations is also included in the learning syllabus. Thus a business and economics ESP learner is expected to be able to apply the communication function from a gestural point of view that is in accordance with the communication culture of native English speakers.

Three lecturers emphasized the importance of gesture, meanwhile thirty four out of forty $(85 \%)$ students considered it as a necessity to understand. Based on the interviews three lecturers uttered that student did not show significant movement in executing gesture in class presentation. Thirty out of forty (75\%) students chose to keep a frozen-style in delivering presentation. They didn't get used to make hand movement although it was taught by the lecturer. Six out of forty (15\%) students argued that hand or body movement was not necessary in delivering presentation, especially in an online/recorded presentation due to Covid-19 pandemic. Only four out of forty students (10\%) attempted to use proper hand movement during presentation. The three lecturers were agree that it was hard to make students move their hands appropriately during presentation.

A handshake is also a form of gesture that needs attention in business and economics ESP subject. Three lecturers introduced and emphasized the importance of handshake in workplace setting. They provided comparison between a Javanese handshake and professional handshake. Forty (100\%) students being involved in this research uttered that shaking hand was one of the most appealing practices in English class. Understanding the differences in communication culture reflected in this kind of kinesics will be an important factor for ESP business and economics learners, especially in their opportunities in the world of work. This is related to the findings of Schroeder, et al. (2019) which states that a handshake is seen as a signal of cooperative intention, increasing people's cooperative behavior and influencing the outcome of agreements that can be made. 
Students being involved were still considering left hand usage for social interaction as taboo, a different perspective compared to English native speakers. Thus, understanding and awareness is important because the culture of the English-speaking community is very open to the use of the left hand in social activities. Lecturers convinced students that it is normal for English native speaker to use left hand, but did not bring the example in their interactions with students.

\section{Non-Verbal Communication: Proxemics}

Proxemics is stated as a study that examines human perceptions of space (personal and social), the way humans use space, and the influence of space in communication (Hall, et al, 1968). Proxemics can also be described as a picture of how humans behave and react in various types of personal space based on culture. Tobing (2016) states that space has a role in facilitating communication interactions that are not realized verbally. Irgin (2017) utters the proximity concept understanding in communication is obligatory for a successful communication since it is often in culture bound, so that what may seem normal to a person in a specific culture context may appear unnecessarily close or distant to a person from other culture. He implies that this concept applies and relatable to career and business context. Regarding to business and economics ESP, it is necessary to ponder that the culture of distance in social interaction among English speakers, namely British and American people is classified as non-contact (Biel, 2010; Pérez, 2019).

Two lecturers of ESP being involved in this research taught general concept of proxemics, yet only one provided further explanation. Twenty nine out of forty (72.5) students were of the opinion that they urged the need of this proxemics. Based on the interviews, there was a certain theme in the prepared material discussing proxemics in general, i.e. in the description of a meeting conducted in an office setting. Students involved in interviews was once has an isolated knowledge about proxemics. Thirty four out of forty $(85 \%)$ students assumed proxemics as a novel acquaintance. Yet, for four out of forty $(10 \%)$ students the concept of keeping distance was treated into the existence of Covid-19 instead of relating it to an ideal communication realization. There was only one out of forty $(2.5 \%)$ student knew this proxemics concept since she was in high school.

\section{Non-Verbal Communication: Artifactual}

Artifactual indicates all things that the physical appearance covers, including clothing, cosmetics, footwear, bags, and so on. Istiyanto (2019) states that the various artifactual realizations found in each culture are visualizations or manifestations of the value and belief systems that apply in that culture. Khozyainova (2017) states that artifactual nonverbal communication has the potential to be the most important aspect of non-verbal communication because of its function as a strong reciprocal trigger from the environment. Thus this aspect of appearance is one of the things necessarily be taught in business and economics ESP because it is closely related to the world of work. In teaching business and economics ESP, understanding of the function and influence of artifactually conveyed messages is expected to provide awareness about the importance of selfphysical-organization which is reflected in individual appearance. Conducted interviews disclosed that the two lecturers prepared and delivered non-specific material of artifactual aspect in business and economics ESP teaching. They provided general information about clothing in work place. Meanwhile, thirty one out of forty $(77.5 \%)$ students were of the opinion that artifactual aspect is mandatorily to understand. 
In general, artifactual communication can be realized through clothing and cosmetics. Aghaei, et al. (2017) state that clothing carries a clear communicative message in terms of social signals, influencing other people's impressions and behavior towards someone. Khozyainova (2017) states that because of the influence and characteristics of the clothing effect, clothing acts as one of the elements of forming a core impression. Twelve out of forty $(30 \%)$ students required further knowledge about the proper one, for example kinds of woman-foot-wear and bag.

Business and economics ESP teaching necessarily need to be fulfilled with an understanding of the colors commonly used in the workplace because the appearance of oneself manifested in the colors of clothing and cosmetics can create a person's selfstatement. Color terminology, color harmony, color preference, color symbolism, and the psychological aspects of color are culturally conditioned, so perceptions of color vary greatly with place and historical period (Colour, n.d). Voevoda (2012) states in terms of physics and physiology, colour perception must be similar for everybody, but representatives of different cultures have differences in perceiving colours. In teaching activity, lecturers did not relate any topic to the discussion about different colour perception among cultures.

\section{CONCLUSION}

English classes in Universitas Putra Bangsa were conducted with cultural approach designed to prepare students for international communication. This cultural approach is manifested in the materials. Verbal communication materials were delivered in the level of words, phrases, clauses, and sentences. Lecturers applied contextual approach for most of levels for it is considered to be the proper one to teach English with cultural understanding enrichments. Students expected to gain more knowledge in terms of words, phrases, clauses, and sentences related to cross-cultural-understanding strategically used in workplace situations. Non-verbal communication aspects were also part of English materials. Kinesics aspects was the most discussed aspect than the proxemics and artifactual in comparison. Practical activities to deepen cross-cultural awareness were favored by students and expected to come quite often in English class. The proxemics and artifactual cross-cultural understanding in workplace setting were also expected to be discussed further.

\section{REFERENCES}

Abusyairi, K. (2013). Pembelajaran bahasa dengan pendekatan budaya. Dinamika Ilmu: Jurnal Pendidikan, 13(2), 174-188. https://doi.org/10.21093/di.v13i2.276

Aghaei, M., Parezzan, F., Dimiccoli, M., Radeva, P., \& Cristani, M. (2017, May). Clothing and people-a social signal processing perspective. In 2017 12th IEEE International Conference on Automatic Face \& Gesture Recognition (FG 2017) (pp. 532-537). IEEE. https://doi.org/10.1109/FG.2017.71

Amzah, N., Hieda, N., \& Nezu, M. (2012). Penyerapan unsur budaya dalam pembelajaran bahasa Jepun. GEMA Online ${ }^{\circledR}$ Journal of Language Studies, 12(2), 407-425.

Biel, Ł. (2010). Proxemic motivation in language: relational metaphors and registers ( $p$. 183-203). Gdańsk: Wydawnictwo Uniwesytetu Gdańskiego.

Britannica.com. (2020, 7 January). Colour. Retrieved 30 April 2021 from https://www.britannica.com/science/color 
Colour. (n.d). Retrieved from Encyclopædia Britannica https://www.britannica.com/science/color

Denscombe, M. (2017). The good research guide: for small-scale social research projects. United Kingdom: McGraw-Hill Education.

Douglas, D. A. N., \& Frazier, S. (2001). Teaching by principles: an interactive approach to language pedagogy: H. Douglas Brown. Tesol Quarterly, 35(2), 341-342. https://doi.org/10.2307/3587655

Fadeeva, A. A., \& Kalinin, V. F. (2012). The importance of cross-cultural understanding for ESL students. Tambov State Technical University, Tambov Recommended for Publication by Doctor of Philology, Professor MN Makeyeva, (4), 42. 144-151.

Hall, E., Birdwhistell, R., Bock, B., Bohannan, P., Diebold, A., Durbin, M., . . . Vayda, A. (1968). Proxemics [and Comments and Replies]. Current Anthropology, 9(2/3), 83108.

Hans, A., \& Hans, E. (2015). Kinesics, haptics and proxemics: Aspects of non-verbal communication. IOSR Journal of Humanities and Social Science, 20(2), 47-52.

Hömke, P., Holler, J., \& Levinson, S. C. (2017). Eye blinking as addressee feedback in face-to-face conversation. Research on Language and Social Interaction, 50(1), 5470. https://doi.org/10.1080/08351813.2017.1262143

Irgin, P. (2017). Paralinguistics in spoken English: investigating the use of proxemics and kinesics in an EFL context. https://doi.org/10.5296/ijl.v9i3.11178

Ishi, E. (2009). The effects of task-based intercultural instruction on the intercultural competence of Japanese secondary EFL learners. Asian Journal of English Language Teaching, 19, 159-181.

Istiyanto, S. B. (2019). Pentingnya komunikasi artifaktual dalam keberhasilan modifikasi komunikasi antarmanusia. Acta diurnA, 6(2), 12-22.

Johnson, J. P., Lenartowicz, T., \& Apud, S. (2006). Cross-cultural competence in international business: Toward a definition and a model. Journal of international business studies, 37(4), 525-543. https://doi.org/10.1057/palgrave.jibs.8400205

Jolly, S. (2000). Understanding body language: Birdwhistell's theory of kinesics. Corporate Communications: An International Journal, 5(3), 133-139. https://doi.org/10.1108/13563280010377518

Khozyainova, N. (2017). Freedom of apparel: artifactual communication as a fundamental human right. Doctoral dissertation. Empire State College.

Koentjaraningrat. (2002). Pengantar ilmu antropologi. Jakarta: PT Rineka Cipta.

Kramsch, C. (2013). Culture in foreign language teaching. Iranian Journal of Language Teaching Research, 1(1), 57-78.

Kusumawati, T. I. (2019). Komunikasi verbal dan nonverbal. Al-Irsyad: Jurnal Pendidikan dan Konseling, 6(2), 83-98. 
Littlejohn, S. W., \& Foss, K. A. (2009). Encyclopedia of communication theory (Vol. 1). Sage.

Mascul, B. (2010). Business vocabulary in use. Cambridge: Cambridge University Press.

Pérez, R. (2019). Awareness of non-verbal language in primary education. programme: predict, systematize and assessment. Undergraduate Thesis. Universidad de Valladolid.

Prakoso, I. (2019). Kesantunan dan solidaritas dalam prespektif komunikasi lintas budaya pada masyarakat Jawa dan Kei. SHAHIH: Journal of Islamicate Multidisciplinary, $4(2), 123-137$.

Pratama, I. (2015). Perlunya pemahaman lintas budaya dalam proses negosiasi bisnis (studi pada PT. Pratama Jaya Perkasa). Jurnal Administrasi Bisnis, 24(1), 1-10.

Pratiwi, B. I., \& Rakhmasari, D. L. (2019). Contextual redefinition strategy for management students. Leksika: Jurnal Bahasa, Sastra, dan Pengajarannya, 12(2), 59-65. https://doi.org/10.30595/lks.v12i2.3354

Poedjosoedarmo, S. (2017). Language propriety in Javanese. Journal of Language and Literature, 17(1), 1 - 9. https://doi.org/10.24071/joll.2017.170101

Ratnasari, D. (2019). The importance of cross-cultural understanding in foreign language teaching in the asian context. Bahasa dan Seni: Jurnal Bahasa, Sastra, Seni, dan Pengajarannya, 46(2), 124-131. https://doi.org/10.17977/um015v46i22018p124

Rondiyah, A. A., Wardani, N. E., \& Saddhono, K. (2017). Pembelajaran sastra melalui bahasa dan budaya untuk meningkatkan pendidikan karakter kebangsaan di era MEA (Masyarakat Ekonomi Asean). In Proceedings Education and Language International Conference (pp 141-147). Semarang, Indonesia: Fakultas Keguruan dan Ilmu Pendidikan, Universitas Sultan Agung.

Schroeder, J., Risen, J. L., Gino, F., \& Norton, M. I. (2019). Handshaking promotes dealmaking by signaling cooperative intent. Journal of personality and social psychology, 116(5), 743. https://doi.org/10.1037/pspi0000157

Schulz, R. A. (2007). The challenge of assessing cultural understanding in the context of foreign language instruction. Foreign language annals, 40(1), 9-26. https://doi.org/10.1111/j.1944-9720.2007.tb02851.x

Scott, H., Batten, J. P., \& Kuhn, G. (2019). Why are you looking at me? It's because I'm talking, but mostly because I'm staring or not doing much. Attention, Perception, \& Psychophysics, 81(1), 109-118. https://doi.org/10.3758/s13414-018-1588-6

Tobing, M. M. (2016). Kosmopolitanisme dalam setting proksemik antarbudaya (studi pada alumni kelas khusus internasional di Australia). In Prosiding Konferensi Nasional Komunikasi Ikatan Sarjana Komunikasi Indonesia (pp. 1-11). Makassar, Indonesia: Ikatan Sarjana Komunikasi Indonesia.

Velentzas, J. O. H. N., \& Broni, G. (2014). Communication cycle: Definition, process, models and examples. In Prosiding Recent advances in financial planning and 
Vol. 02 No. 01 (2022)

product development, (pp. 117-131). Istanbul, Turki: North Atlantic University Union.

Voevoda, E. V. (2012). Colour perception and associative fields in the Russian and English languages. Scientific Newsletter Modern linguistic and methodical-anddidactic research, 1(1), 91-98.

Yuryeva, Y. B. (2019). Address form as a reflection of ethno-cultural style of communication (based on British and Canadian English). RUDN Journal of Language Studies, Semiotics and Semantics, 10(2), 532-543. https://doi.org/10.22363/2313-2299-2019-10-2-532-543 